\title{
EVALUASI KUALITAS ASET RUANG TERBUKA HIJAU DI KOMPLEK PERKANTORAN PEMERINTAH KOTA CIMAHI
}

\author{
Nurlaila Fadjarwati ${ }^{1}$ \\ Tiafahmi Angestiwi ${ }^{2}$ \\ Putri Cantika Noviani ${ }^{3}$ \\ Prodi Manajemen Aset, Jurusan Administrasi Niaga Politeknik Negeri Bandung ${ }^{1,2,3}$ \\ Penulis Korespondensi e-mail: nurlailafadjarwati@yahoo.com
}

\section{ABSTRACT}

Urban green open space (RTHKP) is an important component in each City Regency. The green space owned by Cimahi reaches $13.60 \%$ from a minimum of $30 \%$. One of the RTH in Cimahi City is in the Cimahi City Government Office Complex with an area of 11,115m2. RTH assets are used for parks, motorbike parking lots for guests and the ASN of Cimahi City Government and the rest are still unregulated open green space. The purpose of this study is to describe and define existing problems. The research method in this case study is a descriptive method with a qualitative approach. While the data collection techniques used include scientific observation, interviews and documentation studies. The results of evaluating the quality of RTH assets in the Cimahi City Government office complex are the surrounding communities and visitors need green open space with vegetation, facilities that are complete and attractive. Because the vegetation, facilities are incomplete and unattractive.

Key Word: Evaluation of green open space, green open space

\begin{abstract}
ABSTRAK
Ruang terbuka hijau kawasan perkotaan (RTHKP) merupakan suatu komponen penting di setiap Kota/Kabupaten. Persentase RTH yang ada di Kota Cimahi yaitu mencapai 13,60\% dari minimal ketetapan 30\%. Salah satu RTH yang terdapat di Kota Cimahi berada di Komplek Perkantoran Pemerintah Kota Cimahi dengan luas lahan $11.115 \mathrm{~m}^{2}$. Aset RTH tersebut digunakan untuk taman, tempat parkir sepeda motor para tamu maupun ASN Pemkot Cimahi dan sisanya masih menjadi RTH yang tidak tertata. Tujuan penelitian ini yaitu untuk mendeskripsikan dan mendefinisikan permasalahan yang ada. Metode penelitian yang digunakan pada penelitian studi kasus ini adalah metode deskriptif dengan pendekatan kualitatif. Sedangkan teknik pengumpulan data yang digunakan yaitu meliputi observasi ilmiah, wawancara dan studi dokumentasi. Hasil dari evaluasi kualitas aset RTH di komplek perkantoran Pemerintah Kota Cimahi adalah masyarakat sekitar dan pengunjung membutuhkan RTH dengan vegetasi, fasilitas dan sarana yang lengkap dan menarik. Karena vegetasi, fasilitas dan sarana yang ada tidak lengkap dan tidak menarik.

Kata kunci: Evaluasi Kualitas Ruang Terbuka Hijau, Ruang Terbuka Hijau
\end{abstract}


Jurnal Planologi Vol. 16, No. 1, April 2019

Available : http://jurnal.unissula.ac.id/index.php/psa

\section{PENDAHULUAN}

Ruang Terbuka Hijau Kawasan Perkotaan (RTHKP) merupakan aset yang penting di setiap Kota/Kabupaten. Aset RTHKP memiliki peran penting untuk menjaga keseimbangan ekosistem pada suatu kawasan dan mewujudkan suatu perkotaan menjadi memiliki lingkungan alam yang bersih, indah, segar, dan nyaman untuk ditempati. Selain itu RTHKP juga memiliki fungsi untuk mengurangi aktivitas yang menyebakan pencemaran udara dan air di perkotaan serta bisa menjadi tempat untuk melindungi keanekaragaman hayati. Tidak hanya itu RTHKP pun dapat menjadi tempat rekreasi bagi masyarakat sekitar, yang dapat meningkatkan kesehatan fisik dan psikis masyarakat. Berdasarkan Rencana Tata Ruang Wilayah Kota Cimahi Tahun 2013, bahwa Kota Cimahi tentunya memiliki aset Ruang Terbuka Hijau (RTH) dan pola sebaran RTH yang terdapat di Kota Cimahi yaitu berpola scattered (tersebar), namun untuk saat ini persentase RTH yang ada di Kota Cimahi yaitu mencapai 13,60\% dari minimal ketetapan 30\%.

Salah satu RTH yang terdapat di Kota Cimahi berada di Komplek Perkantoran Pemerintah Kota Cimahi dengan luas lahan $11.115 \mathrm{~m}^{2}$. RTH tersebut merupakan tempat rekreasi bagi masyarakat sekitar maupun masyarakat Kota Cimahi yang berada di luar kawasan RTH dan berpotensi untuk berkunjung. Namun masyarakat Kota Cimahi belum mengetahui keberadaan RTH di dalam komplek perkantoran Pemerintah Kota Cimahi. Saat ini masyarakat yang berkunjung hanya melakukan kegiatan-kegiatan kecil seperti jalan-jalan santai dan menghirup udara segar. Namun saat ini aset RTH tersebut digunakan untuk taman, tempat parkir sepeda motor para tamu maupun Aparat Sipil Negara (ASN) Pemkot Cimahi dan sisanya masih menjadi RTH yang tidak kurang tertata.

Ruang terbuka hijau yang saat ini digunakan untuk taman, jika dilihat dari kondisi fisiknya taman tersebut tidak terawat dan kurang tertata. Gambar 1 berikut dapat dilihat lintasan jogging track yang tertutup tanaman liar yang membuat pengunjung merasa tidak nyaman saat melakukan aktifitas olahraga. 


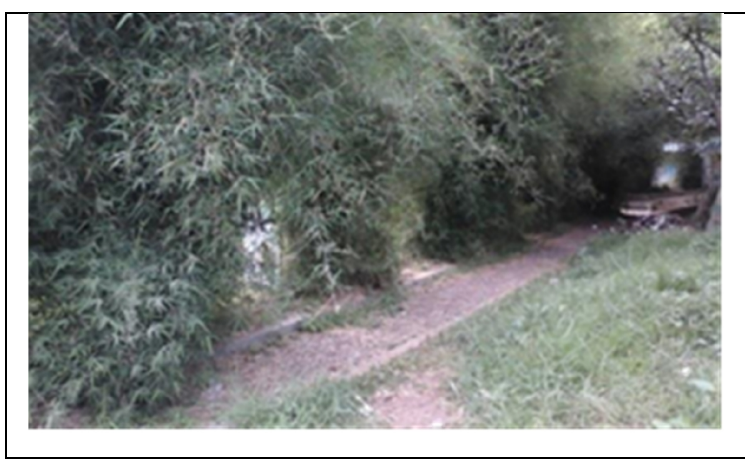

Gambar 1. Lintasan Jogging Track Tidak Terawat Sumber: Peneliti, 2018

Jalur pejalan kaki di area taman pun berserakan sampah-sampah tanaman. Sampah tanaman tersebut seperti ranting-ranting pohon dan daun-daun yang berjatuhan. Hal tersebut dapat membuat pengunjung merasa tidak nyaman dan dapat mengurangi estetika. Selain sampah tanaman yang berserakan, jalur pejalan kaki di area taman terhalangi oleh tanaman liar dan kabel listrik yang menjuntai ke bawah. Hal tersebut dapat menimbulkan risiko kecelakaan dan mengurangi minat pengunjung untuk berekreasi di sekitar taman. Gambar 2a di bawah ini menunjukkan jalur pejalan kaki yang berserakan sampah tanaman, terhalangi rumput liar dan kabel listrik yang menjuntai ke bawah.

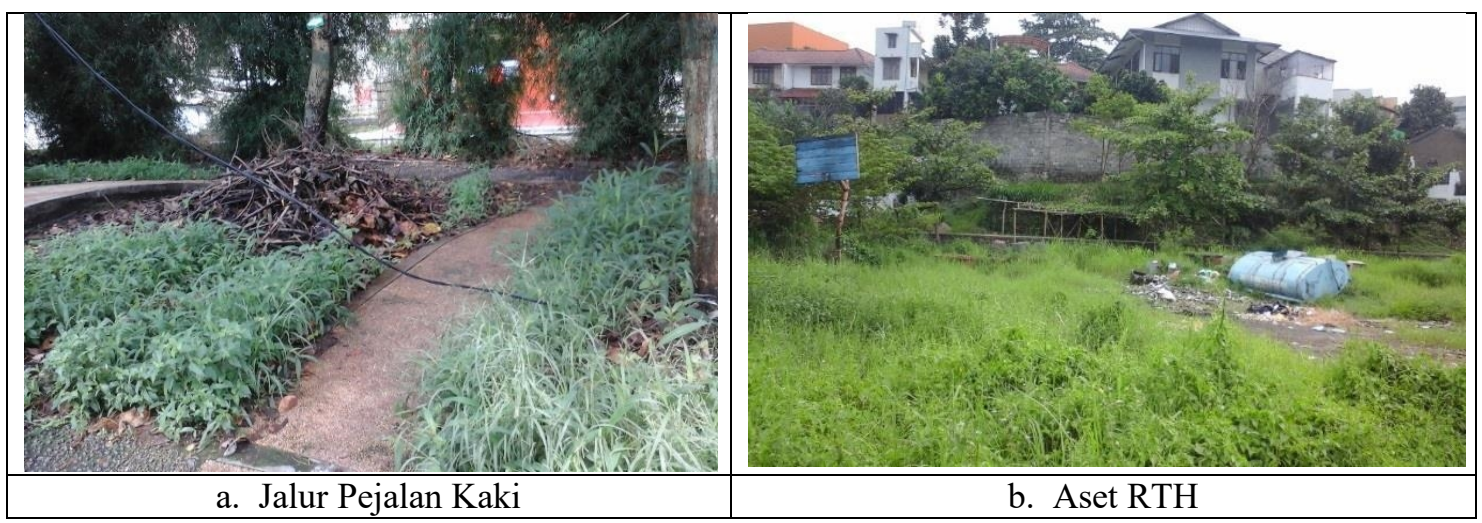

Gambar 2. Aset Tidak Terawat

Sumber: Peneliti, 2018

Selain area taman, aset RTH di komplek perkantoran Pemerintah Kota Cimahi saat ini masih ditumbuhi rumput-rumput liar dan sampah berserakan yang dapat dilihat pada Gambar 2b. Rumput-rumput liar dan sampah yang berserakan tersebut dapat mengurangi estetika dan mengakibatkan pengunjung atau masyarakat sekitar merasa tidak nyaman. 
Sesuai dengan permasalahan yang telah dipaparkan, tujuan penelitian pada ruang terbuka hijau di komplek perkantoran Pemerintah Kota Cimahi yakni mendeskripsikan masalah kualitas aset ruang terbuka hijau berdasarkan aspek:
a. Preferences (Pilihan);
b. Needs (Kebutuhan); dan
c. Use Pattern (Pola Penggunaan).

\section{METODOLOGI}

\section{A. TINJAUAN PUSTAKA}

\section{1) Manajemen Aset}

Menurut Sugiama (2013), pengertian dari manajemen aset yaitu ilmu dan seni untuk mengkoordinasikan segala proses pengelolaan kekayaan/asset dimana mencakup perencanaan kebutuhan asset, pengadaan, penginventarisasian, pelegalan audit, penilaian, pengoperasian, pemeliharaan, pembaharuan, atau penghapusan hingga pengalihan aset secara efektif dan efisien. Manajemen aset memiliki tujuan baik dalam hal bisnis maupun organisasi, agar tujuan yang dinginkan dapat berjalan secara efektif dan efisian maka diperlukan untuk membahas kegiatan terkait mengidentifikasi aset dan biaya yang dibutuhkan, kemudian menyediakan logistik dan sistem untuk mendukung dalam memelihara aset, serta memperbaharui maupun memusnahkan aset (Hastings, 2010). Tujuan lainnya dari manajemen aset menurut Sugiama (2013) yaitu untuk pengambilan keputusan yang tepat sehingga aset yang sedang dikelola bisa berfungsi secara efektif dan efisien. Selain itu Hasting (2010) juga berpendapat terkait tujuan manajemen aset yaitu berguna dalam penunjang penyediaan layanan sehingga bisa berjalan dengan efektif.

\section{2) Evaluasi Kualitas Ruang Terbuka Hijau}

Komite Studi Nasional tentang Evaluasi (National Study Committee on Evaluation) dari UCLA (Stark \& Thomas, 1994: 12), menyatakan bahwa "evaluasi merupakan suatu kegiatan dalam memproses pemilihan, pengumpulan, analisis, serta penyajian informasi sehingga dapat dijadikan sebagai pedoman dalam pengambilan keputusan dan penyusunan program berikutnya”. Selain itu, kualitas adalah tingkat keunggulan yang dimana memuaskan kebutuhan pelanggan (Willie dalam Malek et al, 2012).

Model yang digunakan diharapkan dapat membantu untuk mengevaluasi aspek kualitas ruang terbuka hijau (Malek et al, 2012). Dimensi dan indikator yang diukur terhadap evaluasi kualitas aset ruang terbuka hijau yakni meliputi Preference, Needs, dan 
Jurnal Planologi Vol. 16, No. 1, April 2019

Available : http://jurnal.unissula.ac.id/index.php/psa

\section{Preferences}

Pengertian dari preferensi atau pilihan yang akan diamati dalam konteks ruang terbuka pada lingkungan permukiman maupun taman. Pada saat melakukan pemilihan dalam mengkategorikan ruang terbuka yaitu perlu melihat dari 3 indikator yang berupa faktor alam, faktor motivasi sosial dan budaya, faktor ruang, serta faktor desain. Ada beberapa hal yang disukai berkaitan dengan alam sekitar dan membuktikan bahwa pemandangan alam leih menarik dan disukai daripada pemandangan suatu kota (Kaplan dalam Malek et al, 2012).

Perencanaan RTH taman lingkungan harus sesuai dengan preferensi masyarakat yang dilengkapi dengan fasilitas umum berupa taman bermain, tempat duduk pengunjung, dan lahan khusus untuk pedagang atau PKL (Muchran et al, 2015). Mayoritas pandangan masyarakat bahwa pemandangan dengan tingkat vegetasi rendah, tingkat keterbukaan, dan aksesibilitas tertinggi menjadi aspek penting dalam mencapai suatu tujuan

Menurut Malek et al (2012) indikator yang penting untuk diamati dalam aspek preferences yaitu faktor alam sekitar (natural sorrounding factors), faktor ruang dan desain (spaces and design factors), faktor motivasi budaya dan sosial (cultural and social motivation factors).

\section{Needs}

Malek et al (2012) berpendapat bahwa mayoritas orang memiliki sifat saling berbagi yaitu berbagi kebutuhan satu sama lain, namun dalam hal kebutuhan setiap orang masing-masing memiliki ciri untuk memenuhi kebutuhannya dengan cara unik baik dalam mengekspresikan bahkan memuaskan kebutuhanya. Indikator penting yang perlu ditinjau pada aspek ini merupakan kebutahan dari interaksi manusia (human interaction needs) dan kebutuhan alam (nature needs).

\section{Use Pattern}

Malek et all (2012) menyatakan bahwa dalam pengelompokannya pola penggunaan pada ruang terbuka hijau dapat dibedakan menjadi dua meliputi penggunaan (usage) rekreasi aktif dan rekreasi pasif. Selain itu pola pengunaan (pattern of use) dapat dibedakan juga menjadi ruang yang dimanfaatkan dan fokus pengguna. Menurut Malek et al (2012) indikator yang perlu diamati pada aspek use pattern adalah penggunaan (usage) dan pola penggunaan (pattern of use). Berdasarkan penggunaannya dapat dikategorikan untuk 
rekreasi aktif dan rekreasi pasif. Sedangkan berdasarkan pola penggunaannya, RTH dapat dilakukan pemanfaatan ruang dan fokus pada pengguna

\section{3) Ruang Terbuka Hijau}

Berdasarkan PPG17 (2008) definisi dari ruang terbuka yaitu suatu lahan yang ditata dan dikelola sebagai beberapa fasilitas berupa taman, keperluan rekreasi umum, dan dapat juga sebagai tempat pemakaman umum. Ruang terbuka hijau sendiri dapat diartikan sebagai lahan yang diperuntukkan untuk tempat rekreasi bisa berupa taman maupun jalur hijau sehingga diharapkan dapat meningkatkan kesehatan, kesejateraan masyarakat, dan menyeimbangkan ekosistem serta iklim perkotaan. Sedangkan fungsi RTH kawasan perkotaan menurut Peraturan Menteri Pekerjaan Umum No.5 Tahun 2008 tentang pedoman penyediaan dan pemanfaatan ruang terbuka hijau dapat dijelaskan pada tabel 1 dibawah ini.

Tabel 1. Fungsi RTH Berdasarkan Pedoman Penyediaan dan Pemanfaatan Ruang Terbuka Hijau

\begin{tabular}{|c|c|c|c|}
\hline \multirow{2}{*}{$\begin{array}{c}\text { Fungsi Utama } \\
\quad \text { (intrinsik) }\end{array}$} & \multicolumn{3}{|c|}{ Fungsi Tambahan (ekstrinsik) } \\
\hline & in & ni & $\mathbf{x a}$ \\
\hline $\begin{array}{lr}\text { a. Memberi } & \text { jaminan } \\
\text { pengadaan } & \text { RTH } \\
\text { sebagai salah } & \text { satu } \\
\text { bagian dari } & \text { sistem } \\
\text { sirkulasi udara } & \text { (paru- } \\
\text { paru kota); pengatur } \\
\text { iklim mikro agar dapat } \\
\text { berjalan lancar dengan } \\
\text { menjaga } & \text { sistem } \\
\text { sirkulasi udara dan air } \\
\text { secara alami } \\
\text { b. Sebagai } \\
\text { produsen } \\
\text { c. Oksigen }\end{array}$ & $\begin{array}{l}\text { a. Menggambarkan } \\
\text { wajah budaya lokal } \\
\text { b. Sebagai media } \\
\text { komunikasi untuk } \\
\text { masayarakat di kota } \\
\text { c. Sarana rekreasi } \\
\text { d. Sebagai wadah dan } \\
\text { objek pendidikan, } \\
\text { penelitian, dan } \\
\text { pelatihan dalam } \\
\text { memahami dan } \\
\text { belajar tentang alam }\end{array}$ & 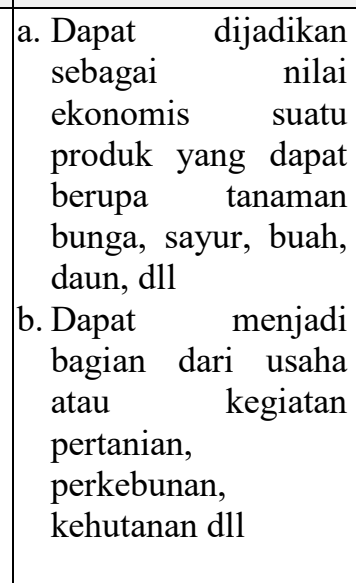 & $\begin{array}{l}\text { kenyamanan, } \\
\text { keindahan } \\
\text { lingkungan kota dari } \\
\text { skala mikro dan } \\
\text { halaman } \\
\text { b. Rumah, lingkungan } \\
\text { permukiman, maupun } \\
\text { makro; lansekap kota } \\
\text { secara keseluruhan } \\
\text { c. Menstimulasi dan } \\
\text { kreativitas } \\
\text { produktivitas warga }\end{array}$ \\
\hline
\end{tabular}

Sumber: Permen PU No.5/2008

\section{B. Metode Penelitian}

Metode penelitian yang digunakan pada penelitian evaluasi kualitas aset ruang terbuka hijau di komplek perkantoran Pemkot Cimahi adalah metode deskriptif dengan pendekatan kualitatif. Data yang dibutuhkan pada penelitian ini adalah data primer dan data sekunder. Menurut Sugiama (2013) Pengumpulan data primer dimulai dari melakukan survey, observasi atau pengamatan, maupun dengan eksperimen. Sedangkan data sekunder merupakan data yang diperoleh dari pihak lain dimana data ini dijadikan sebagai sarana kepentingan dari pihak ini sendiri (Sugiama, 2013). 
Teknik pengumpulan data yang dilakukan dalam memperoleh data primer yaitu dimulai dengan melaukan observasi atau pengamatan ilmiah dan wawancara mengenai aset ruang terbuka hijau di komplek perkantoran Pemerintah Kota Cimahi. Sedangkan untuk memperoleh data sekunder adalah dengan studi dokumentasi melalui jurnal atau data-data yang didapatkan dari publikasi pemerintah (studi normatif) yang masih berlaku. Selain itu operasionalisasi yang disusun dalam penelitian ini dapat dilihat pada rincian Tabel 2 berikut ini.

Tabel 2. Operasionalisasi Variabel

\begin{tabular}{|c|c|c|c|c|}
\hline Variabel & Dimensi & Indikator & Butir Pertanyaan & $\begin{array}{c}\text { Teknik } \\
\text { Pengumpulan } \\
\text { Data }\end{array}$ \\
\hline \multirow{14}{*}{$\begin{array}{l}\text { Kualitas } \\
\text { Ruang } \\
\text { Terbuka Hijau } \\
\text { adalah alat } \\
\text { atau model } \\
\text { yang } \\
\text { digunakan } \\
\text { untuk } \\
\text { mengevaluasi } \\
\text { kualitas rang } \\
\text { terbuka hijau } \\
\text { yang ditinjau } \\
\text { dari: } \\
\text { 1. Preference } \\
\text { 2. Needs } \\
\text { 3. Use } \\
\text { Pattern } \\
\text { (Malek et } \\
\text { al, 2012) }\end{array}$} & \multirow{13}{*}{$\begin{array}{l}\text { 1. Preference } \\
\text { Tempat favorit } \\
\text { yang menjadi } \\
\text { preferensi } \\
\text { masyarakat } \\
\text { adalah tempat- } \\
\text { tempat alami, } \\
\text { tempat tinggal, } \\
\text { area rekreasi, } \\
\text { waktu luang } \\
\text { dan peturan } \\
\text { pengatur raga, } \\
\text { olah pengaturan } \\
\text { ritel, } \\
\text { pengaturan } \\
\text { transportasi } \\
\text { dan } \\
\text { pengaturan } \\
\text { layanan } \\
\text { masyarakat } \\
\text { (Malek et al, } \\
\text { 2012) }\end{array}$} & \multirow{2}{*}{$\begin{array}{l}\text { 1. Faktor alam } \\
\text { sekitar } \\
\text { (natural } \\
\text { surroundin } \\
\text { g factors) }\end{array}$} & $\begin{array}{l}\text { 1. Berapa persen RTH di } \\
\text { Kota Cimahi }\end{array}$ & $\begin{array}{l}\text { Wawancara dan } \\
\text { studi dokumentasi }\end{array}$ \\
\hline & & & $\begin{array}{l}\text { 2. Apakah daerah sekitar } \\
\text { merupakan daerah } \\
\text { padat penduduk }\end{array}$ & Observasi ilmiah \\
\hline & & \multirow{7}{*}{$\begin{array}{l}\text { 2. Faktor } \\
\text { ruang dan } \\
\text { desain } \\
\text { (space and } \\
\text { design } \\
\text { factors) }\end{array}$} & $\begin{array}{l}\text { 1. Apakah ada lintasan } \\
\text { untuk pejalan kaki } \\
\text { yang layak? }\end{array}$ & Observasi ilmiah \\
\hline & & & $\begin{array}{l}\text { 2. Apakah ada lintasan } \\
\text { untuk pejalan kaki } \\
\text { yang aman? }\end{array}$ & Observasi ilmiah \\
\hline & & & $\begin{array}{l}\text { 3. Apakah ada tempat } \\
\text { duduk } \\
\text { pengunjung? }\end{array}$ & Observasi ilmiah \\
\hline & & & $\begin{array}{l}\text { 4. Apakah ada fasilitas } \\
\text { khusus } \\
\text { penyandang disabilitas }\end{array}$ & Observasi ilmiah \\
\hline & & & $\begin{array}{l}\text { 5. Apakah tersedia } \\
\text { sarana olah raga }\end{array}$ & Observasi ilmiah \\
\hline & & & $\begin{array}{l}\text { 6. Apakah tersedia arena } \\
\text { bermain anak? }\end{array}$ & Observasi ilmiah \\
\hline & & & $\begin{array}{l}\text { 7. Apakah tersedia } \\
\text { kawasan untuk penjual } \\
\text { makanan? }\end{array}$ & Observasi ilmiah \\
\hline & & \multirow{4}{*}{$\begin{array}{ll}\text { 3. } & \text { Faktor } \\
\text { motivasi } \\
\text { budaya dan } \\
\text { sosial } \\
\text { (cultural } \\
\text { and social } \\
\text { motivation } \\
\text { factors) }\end{array}$} & $\begin{array}{l}\text { 1. Apakah di area RTH } \\
\text { dipasang pagar? }\end{array}$ & $\begin{array}{l}\text { Wawancara } \\
\text { observasi }\end{array}$ \\
\hline & & & $\begin{array}{l}\text { 2. Apakah ada personel } \\
\text { keamanan khusus di } \\
\text { sekitar lahan RTH }\end{array}$ & $\begin{array}{l}\text { Wawancara dan } \\
\text { Observasi ilmiah }\end{array}$ \\
\hline & & & $\begin{array}{ll}\text { 3. Apakah ada } & \text { personel } \\
\text { pemeliharaan } & \text { khusus } \\
\text { untuk RTH } & \\
\end{array}$ & Observasi ilmiah \\
\hline & & & $\begin{array}{l}\text { 4. Apakah di sekitar RTH } \\
\text { terdapat cafe? }\end{array}$ & Observasi ilmiah \\
\hline & $\begin{array}{l}\text { 2. Needs } \\
\text { Persyaratan } \\
\text { apa yang }\end{array}$ & $\begin{array}{l}\text { 1. Interaksi } \\
\text { sosial } \\
\text { (social }\end{array}$ & $\begin{array}{l}\text { 2. Apakah ada kegiatan } \\
\text { atau event yang } \\
\begin{array}{ll}\text { diadakan } & \text { oleh }\end{array}\end{array}$ & Wawancara \\
\hline
\end{tabular}


Jurnal Planologi Vol. 16, No. 1, April 2019

Available : http://jurnal.unissula.ac.id/index.php/psa

\begin{tabular}{|c|c|c|c|c|}
\hline Variabel & Dimensi & Indikator & Butir Pertanyaan & $\begin{array}{c}\text { Teknik } \\
\text { Pengumpulan } \\
\text { Data }\end{array}$ \\
\hline & \multirow{10}{*}{$\begin{array}{l}\text { masyarakat } \\
\text { harapkan } \\
\text { tentang RTH } \\
\text { yang } \\
\text { memuaskan } \\
\text { mereka } \\
\text { (Malek, 2012) }\end{array}$} & \multirow[t]{2}{*}{ interaction) } & $\begin{array}{l}\text { masyarakat kota } \\
\text { Cimahi di area RTH } \\
\text { komplek perkantoran } \\
\text { Kota Cimahi? }\end{array}$ & \\
\hline & & & $\begin{array}{l}\text { 3. Kegiatan apa saja yang } \\
\text { sering dilakukan di } \\
\text { area RTH? }\end{array}$ & $\begin{array}{l}\text { Wawancara dan } \\
\text { observasi ilmiah }\end{array}$ \\
\hline & & \multirow{2}{*}{$\begin{array}{l}\text { 2. Partisipasi } \\
\text { masyarakat } \\
\text { dalam } \\
\text { proses } \\
\text { desain } \\
\text { (citizen } \\
\text { participatio } \\
n \text { in design } \\
\text { process) }\end{array}$} & $\begin{array}{l}\text { 1. Apakah ada partisipasi } \\
\text { masyarakat dalam } \\
\text { proses desain RTH di } \\
\text { Komplek perkantoran } \\
\text { Pemkot Cimahi }\end{array}$ & Wawancara \\
\hline & & & $\begin{array}{l}\text { 2. Siapa pemilik dari aset } \\
\text { RTH di } \\
\text { perkantoran } \\
\text { Cimahi }\end{array}$ & Wawancara \\
\hline & & \multirow{2}{*}{$\begin{array}{l}\text { 3. Rekreasi } \\
\text { dan } \\
\text { permainan } \\
\text { (recreation } \\
\text { and play) }\end{array}$} & $\begin{array}{l}\text { 1. Apakah membutuhkan } \\
\text { lintasan atau arena } \\
\text { bermain sepeda }\end{array}$ & Wawancara \\
\hline & & & $\begin{array}{l}\text { 2. Siapa pemilik dari aset } \\
\text { RTH di } \\
\text { perkantoran } \\
\text { Cimahi }\end{array}$ & Wawancara \\
\hline & & $\begin{array}{l}\text { 4. Kontak } \\
\text { dengan alam } \\
\text { (contact with } \\
\text { nature) }\end{array}$ & $\begin{array}{l}\text { Apakah pengunjung dapat } \\
\text { merasakan ketenangan } \\
\text { saat berada di area RTH? }\end{array}$ & Wawancara \\
\hline & & \multirow{3}{*}{$\begin{array}{l}\text { 5.Preferensi } \\
\text { estetika } \\
\text { (aesthetic } \\
\text { preferences) }\end{array}$} & $\begin{array}{l}\text { 1. Apakah kondisi area } \\
\text { RTH bersih? }\end{array}$ & Observasi ilmiah \\
\hline & & & $\begin{array}{l}\text { 2. Apakah fasilitas yang } \\
\text { ada di area RTH dalam } \\
\text { kondisi terawat? }\end{array}$ & Observasi ilmiah \\
\hline & & & $\begin{array}{l}\text { 3. Apakah di area RTH } \\
\text { terdapat suara-suara } \\
\text { pepohonan dan suara- } \\
\text { suara hewan }\end{array}$ & Observasi ilmiah \\
\hline & \multirow[t]{5}{*}{$\begin{array}{l}\text { 3. Use } \\
\text { Pattern }\end{array}$} & \multirow[t]{2}{*}{$\begin{array}{l}\text { Rekreasi } \\
\text { aktif (active } \\
\text { recreation) }\end{array}$} & $\begin{array}{l}\text { 1. Apakah lintasan } \\
\text { pejalan kaki di area } \\
\text { RTH sering digunakan }\end{array}$ & Observasi ilmiah \\
\hline & & & $\begin{array}{l}\text { 2. Apakah sarana } \\
\text { olahraga di area RTH } \\
\text { sering digunakan? }\end{array}$ & Observasi ilmiah \\
\hline & & $\begin{array}{l}\text { 2. Rekreasi } \\
\text { pasif (pasive } \\
\text { recreation) }\end{array}$ & $\begin{array}{l}\text { Aktivitas seperti apa } \\
\text { sajakah yang sering } \\
\text { dilakukan di area RTH? }\end{array}$ & Observasi ilmiah \\
\hline & & $\begin{array}{l}\text { 3. Pemanfaata } \\
\mathrm{n} \quad \text { ruang } \\
\text { (space } \\
\text { utilized) }\end{array}$ & $\begin{array}{l}\text { Apakah RTH penting } \\
\text { dalam kehidupan } \\
\text { hari? }\end{array}$ & Wawancara \\
\hline & & 4. Fokus & keberadaan & Wawancara \\
\hline
\end{tabular}


Jurnal Planologi Vol. 16, No. 1, April 2019

\begin{tabular}{|l|l|l|l|l|}
\hline Variabel & Dimensi & Indikator & Butir Pertanyaan & $\begin{array}{c}\text { Teknik } \\
\text { Pengumpulan } \\
\text { Data }\end{array}$ \\
\hline \multirow{2}{*}{} & & $\begin{array}{l}\text { pengguna } \\
\text { (user focus })\end{array}$ & $\begin{array}{l}\text { RTH diperlukan untuk } \\
\text { orang dewasa }\end{array}$ & \\
\cline { 4 - 5 } & & $\begin{array}{l}\text { 2. Apakah keberadaan } \\
\text { RTH diperlukan untuk } \\
\text { remaa? }\end{array}$ & Wawancara \\
\cline { 4 - 5 } & & $\begin{array}{l}\text { 3. Apakah keberadaan } \\
\text { RTH diperlukan untuk } \\
\text { anak-anak? }\end{array}$ & Wawancara \\
& & & \\
\hline
\end{tabular}

\section{HASIL DAN PEMBAHASAN}

Berdasarkan hasil penelitian melalui observasi ilmiah, wawancara dan studi dokumentasi dapat diketahui kualitas aset ruang terbuka hijau di Komplek Perkantoran Pemerintah Kota Cimahi yang ditinjau dari aspek Preferences, Needs dan Use Pattern.

\section{A. Evaluasi Aspek Preferences}

Evaluasi aspek preferences pada kualitas aset RTH di Komplek Perkantoran Pemerintah Kota Cimahi dibagi menjadi 3 indikator yakni faktor alam sekitar, ruang dan desain, serta motivasi budaya dan sosial. Hasil evaluasi aspek preferences dapat dijelaskan pada Tabel 3 berikut ini.

Tabel 3. Hasil Evaluasi Aspek Preferences

\begin{tabular}{|l|l|l|}
\hline Indikator & Kriteria & Kondisi Eksisting \\
\hline Faktor alam sekitar & Ketersediaan RTH di Kota & Kurang \\
\cline { 2 - 3 } & Kepadatan penduduk di sekitar & Tinggi \\
\hline $\begin{array}{l}\text { Faktor Ruang dan } \\
\text { Desain }\end{array}$ & Jalur pejalan kaki yang aman dan layak & $\begin{array}{l}\text { Ada, namun tidak aman dan } \\
\text { tidak layak }\end{array}$ \\
\hline \multirow{5}{*}{$\begin{array}{l}\text { Motivasi } \\
\text { Tempat duduk }\end{array}$} & Tidak ada \\
\cline { 2 - 3 } & $\begin{array}{l}\text { Fasilitas khusus untuk penyandang } \\
\text { disabilitas }\end{array}$ & Tidak ada \\
\cline { 2 - 3 } & Fasilitas luar ruangan (sarana olahraga) & $\begin{array}{l}\text { Ada, namun tidak terawat dan } \\
\text { tidak layak }\end{array}$ \\
\cline { 2 - 3 } & $\begin{array}{l}\text { Easilitas luar ruangan (area bermain } \\
\text { anak) }\end{array}$ & Tidak ada \\
\cline { 2 - 3 } & Fasilitas luar ruangan (kawasasn khusus & Tidak ada \\
\cline { 2 - 3 } $\begin{array}{l}\text { Faktor } \\
\text { Budaya dan Sosial }\end{array}$ & Unsur peamanan & Ada, namun masih kurang \\
\hline
\end{tabular}

Sumber: Peneliti, 2019

\section{Faktor Alam Sekitar}

Kualitas RTH akan mempengaruhi pola aktivitas masyarakat agar mempunyai kesempatan untuk bersantai dari stress. Berdasarkan hasil wawancara dengan staf Bidang 
Tata Lingkungan di Dinas Lingkungan Hidup, saat ini persentase RTH di Kota Cimahi baru mencapai 13,60\%. Selain itu hasil studi dokumentasi dengan mengkaji peraturan terkait, persentase minimal RTH di kawasan perkotaan yaitu sebesar 30\%. Berdasarkan kondisi tersebut dapat dikatakan bahwa Kota Cimahi masih kekurangan RTH.

Berdasarkan hasil observasi ilmiah, di sekitar RTH komplek perkantoran Pemkot Cimahi merupakan daerah padat penduduk. Padat nya penduduk di suatu daerah dapat meningkatkan polusi udara dan iklim setempat. Terlebih lagi di sekitar daerah padat penduduk tersebut belum tersedia RTH yang berkualitas. Kondisi tersebut akan meningkatkan kebutuhan masyarakat sekitar mengenai ruang terbuka hijau yang berkualitas. Selain itu padatnya penduduk pun dapat menjadi potensi rekreasi di ruang terbuka hijau yang berkualitas.

\section{Faktor Ruang dan Desain}

Fasilitas yang mendukung pada faktor ruang dan desain adalah tersedianya jalur pejalan kaki yang aman dan layak, fasilitas luar ruangan (sarana olahraga, arena bermain anak dan kawasan khusus penjual) banyaknya tempat duduk, fasilitas untuk penyandang disabilitas. Berdasarkan hasil obervasi ilmiah pada RTH di Komplek Perkantoran Pemkot Cimahi tidak terdapat jalur pejalan kaki yang aman dan layak. Jalur pejalan kaki yang ada saat ini dalam kondisi yang tidak aman karena tidak ada pembatas antara jalur pejalan kaki dengan sungai, sehingga dapat menimbulkan risiko kecelakaan. Jalur pejalan kaki yang tidak aman dapat dilihat pada Gambar $3 a$.

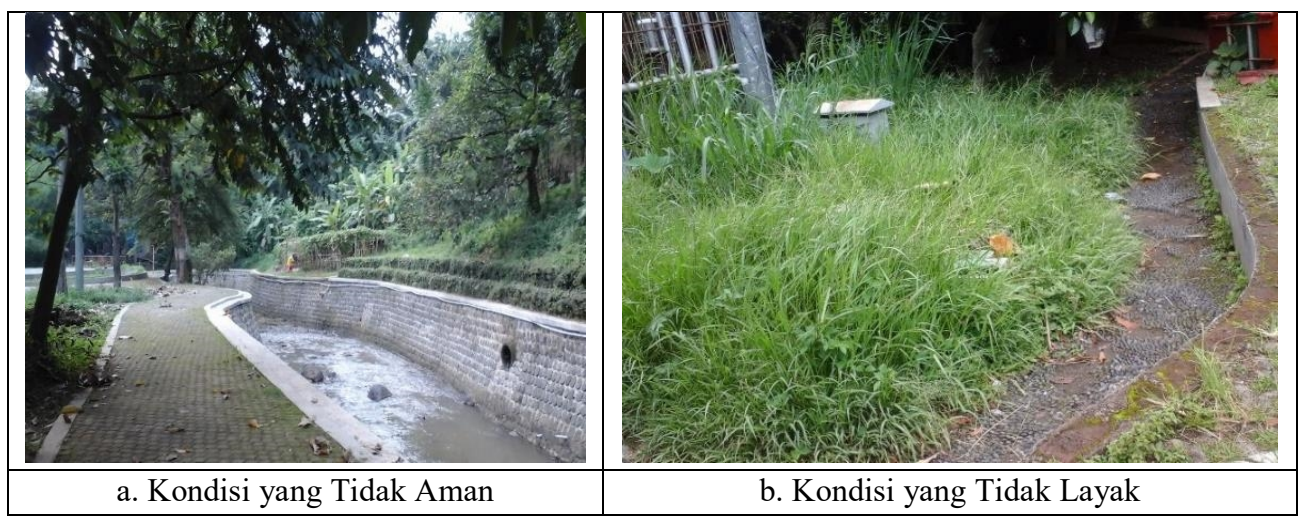

Gambar 3. Kondisi Jalur Pejalan Kaki

Sumber: Peneliti, 2018

Selain tidak ada pembatas antara jalur pejalan kaki dengan sungai, terdapat jalur pejalan kaki di area taman saat ini dalam kondisi tidak layak. Jalur pejalan kaki tersebut tertutupi oleh rumput-rumput liar dan pada permukaan lantai nya terdapat lumut-lumut 
sehingga permukaan jalur menjadi licin. Kondisi tersebut dapat menimbulkan risiko kecelakaan pada pengunjung seperti terpeleset. Gambar jalur pejalan kaki yang tidak layak dapat dilihat pada Gambar 3b.

\section{Faktor Motivasi Budaya dan Sosial}

Berdasarkan hasil observasi ilmiah unsur sosial pada area RTH dapat dilihat dari tidak adanya pagar yang membatasi area RTH. Tidak adanya pagar pembatas pada RTH melambangkan bahwa semua lapisan masyarakat dapat menggunakan fasilitas atau sarana yang ada di RTH komplek perkantoran Pemerintah Kota Cimahi. Unsur sosial yang lainnya yaitu adanya tempat makan dan minum. Keberadaan tempat makan dan minum di area RTH dapat meningkatkan aktivitas sosial seperti berkumpul

\section{B. Evaluasi Aspek Needs}

Evaluasi aspek needs adalah untuk menggambarkan persyaratan apa yang penduduk atau masyarakat harapkan tentang ruang terbuka hijau. Pada evaluasi aspek needs aset RTH di Komplek Perkantoran Pemerintah Kota Cimahi meliputi kebutuhan interaksi manusia dan kebutuhan alam dapat dilihat pada penjelasan tabel 4 berikut.

Tabel 4. Hasil Evaluasi Aspek Needs

\begin{tabular}{|l|l|l|}
\hline Dimensi & Indikator & Hasil Evaluasi \\
\hline \multirow{2}{*}{$\begin{array}{l}\text { Kebutuhan Interaksi } \\
\text { Kebutuhan Alam }\end{array}$} & Interaksi Sosial & RTH sebagai ruang publik untuk bersosialisasi \\
\cline { 2 - 3 } & Partisipasi Masyarakat & $\begin{array}{l}\text { RTH publik memudahkan masyarakat untuk } \\
\text { berpartisipasi dan berekreasi }\end{array}$ \\
\cline { 2 - 3 } & Preferensi Estetika & $\begin{array}{l}\text { Membutuhkan vegetasi dengan penyebaran } \\
\text { yang merata }\end{array}$ \\
\cline { 2 - 3 } & Rekreasi dan Bermain & $\begin{array}{l}\text { Membutuhkan RTH yang bersih dan fasilitas } \\
\text { serta vegetasi yang menarik }\end{array}$ \\
\hline $\begin{array}{l}\text { Membutuhkan lintasan sepeda dan arena } \\
\text { bermain anak }\end{array}$ \\
\hline
\end{tabular}

Sumber: Peneliti, 2018

\section{Kebutuhan Interaksi Manusia}

Saat ini kegiatan masyarakat yang dilakukan di area RTH meliputi berjalan-jalan santai, anak-anak yang bermain bola dan tamu Pemkot yang memarkirkan kendaraan nya. Sedangkan hasil evaluasi partisipasi masyarkat, diperoleh informasi dari hasil wawancara dengan staf Tata Lingkungan di Dinas Lingkungan Hidup masyarakat sekitar belum berpartisipasi secara langsung untuk proses desain. 
Jurnal Planologi Vol. 16, No. 1, April 2019

\section{Kebutuhan Alam}

Bentuk kontak dengan alam adalah masyarakat atau pengunjung merasa tenang saat berada di area RTH. Rasa ketenangan muncul dari lingkungan alam yang dapat menstabilkan emosi dan mental. Berdasarkan hasil wawancara dengan pengunjung RTH, pengunjung merasa tidak tenang saat berada di area RTH komplek perkantoran Pemerintah Kota Cimahi. Hal tersebut disebabkan oleh vegetasi yang kurang melindungi dari panas matahari serta kurangnya kebersihan alam di area RTH. Sedangkan berdasarkan hasil observasi ilmiah, lingkungan sekitar RTH dapat dikatakan kotor. Kondisi saluran air yang ada di area taman RTH dalam keadaan keruh, hal tersebut disebabkan oleh adanya sampah di saluran air. Hal itu dapat menimbulkan bau tidak sedap dan membuat pengunjung merasa tidak nyaman. Gambar 4 merupakan saluran air yang keruh di area taman RTH.

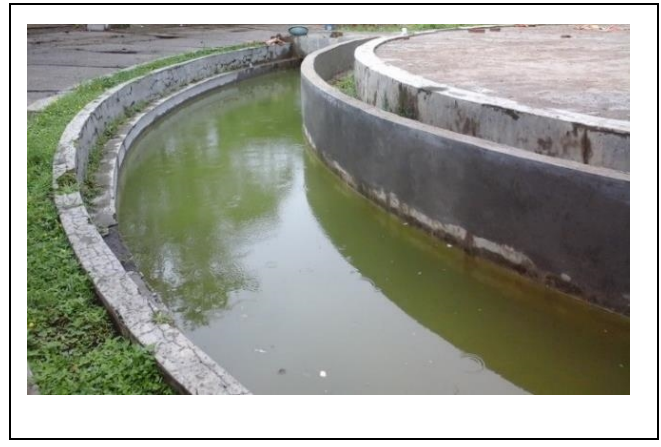

Gambar 4. Saluran Air yang Keruh di Area Taman RTH Sumber: Peneliti

Selain itu, kebersihan RTH di komplek perkantoran Pemerintah Kota Cimahi pun sangat rendah. Hal tersebut dilihat dari adanya tumpukan sampah di area RTH yang dapat membuat pengunjung merasa tidak nyaman dan mengurangi estetika. Tumpukan sampah di area RTH dapat dilihat pada Gambar 5.

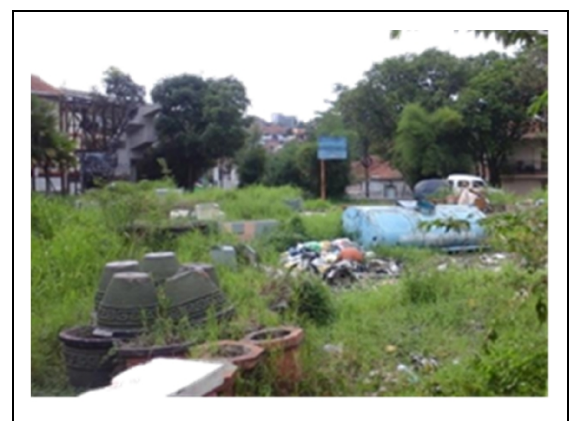

Gambar 5. Tumpukan Sampah di Area RTH Sumber: Peneliti, 2018 
Tidak hanya kebersihan RTH yang mempengaruhi estetika, melainkan kemerduan suara alam pun dapat mempengaruhi. Kemerduan suara alam dapat berasal dari suara pepohonan yang tertiup angin, suara hewan seperti burung, dan suara aliran air. RTH di komplek perkantoran Pemerintah Kota Cimahi saat ini tidak memiliki estetika dari segi kemerduan suara alam, karena kurangnya vegetasi yang berestetika dan kurangnya suara hewan seperti burung karena sedikitnya pohon rindang di sekitar RTH.

\section{Evaluasi Aspek Use Pattern}

Berdasarkan hasil evaluasi aspek use pattern dengan dua indikator yaitu penggunaan dan pola penggunaan, hasil evaluasi RTH Komplek Perkantoran Kota Cimahi dapat dilihat pada Tabel 5

Tabel 5. Hasil Evaluasi Aspek Use Pattern

\begin{tabular}{|l|l|l|}
\hline \multicolumn{1}{|c|}{ Dimensi } & Indikator & Hasil Evaluasi \\
\hline Penggunaan & Rekreasi Aktif & Cukup serin pada jalur pejalan kaki saja \\
\cline { 2 - 3 } & Rekreasi Pasif & $\begin{array}{l}\text { Tidak ada penggunaan karena tidak tersedia tempat duduk } \\
\text { dan cafe bagi pengunjung }\end{array}$ \\
\hline $\begin{array}{l}\text { Pola } \\
\text { Penggunaan }\end{array}$ & $\begin{array}{l}\text { Pemanfaatan } \\
\text { Ruang }\end{array}$ & $\begin{array}{l}\text { Tidak ada pemanfaatan pada RTH karena fasilitas dan } \\
\text { sarana yang ada kurang menarik }\end{array}$ \\
\cline { 2 - 3 } & Fokus Pengguna & Tidak ada, karena tidak tersedia arena bermain anak \\
\hline
\end{tabular}

Sumber: Peneliti, 2019

\section{Penggunan (usage)}

Masyarakat yang beraktifitas untuk berekreasi di RTH bermacam-macam, aktifitas aktif yang dilakukan berupa jalan-jalan santai, bermain basket, jogging dan bersepeda. Berdasarkan hasil observasi ilmiah jalur pejalan kaki pada RTH komplek perkantoran Pemerintah Kota Cimahi cukup sering digunakan. Hal tersebut dikarenakan aktivitas yang sering dilakukan adalah jalan-jalan santai di area taman RTH. Selain itu, jogging track pun jarang digunakan oleh pengunjung, karena rendahnya motivasi untuk berlari di lintasan disebabkan oleh lintasan yang tidak terawat

Rekreasi aktif lain nya yaitu bermain basket dan bersepeda tidak bisa dilakukan karena tidak adanya ring basket yang layak dan tidak adanya lintasan sepeda. Saat ini sarana olah raga yang ada yaitu ring basket dan wall climbing. Namun kondisi dari sarana olahraga tersebut saat ini dapat dikatakan tidak layak karena sarana tersebut merupakan sisa-sisa kebakaran yang belum direnovasi. Gambar 6 menunjukkan kondisi ring basket yang sudah rusak. 


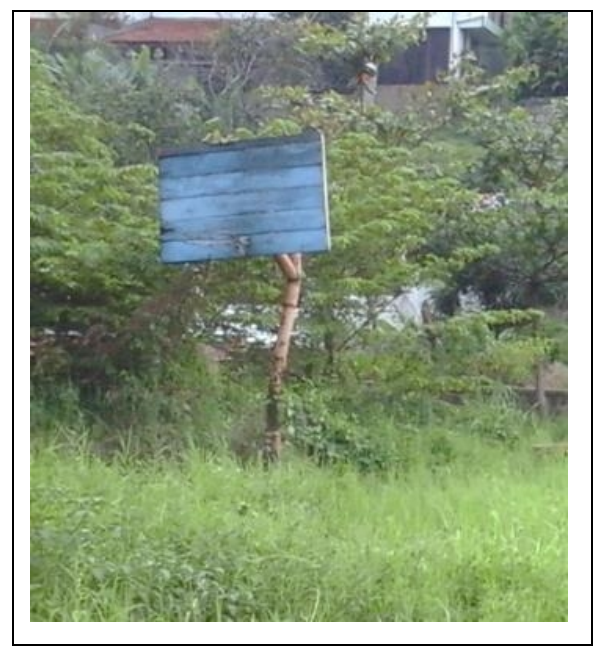

Gambar 6. Ring Basket yang Rusak Sumber: Peneliti, 2018

Rekreasi pasif yang dilakukan oleh pengunjung RTH antara lain dilakukan di kafe dan hanya duduk-duduk di area RTH. Berdasarkan hasil observasi ilmiah, tidak ada rekreasi pasif yang dilakukan oleh pengunjung di RTH komplek perkantoran Pemerintah Kota Cimahi. Hal tersebut diakibatkan oleh, belum tersedianya kafe dan tempat duduk untuk pengunjung RTH.

\section{Pola Penggunaan}

Pola penggunaan aset RTH meliputi pemanfaatan ruang dan fokus penggunaan. Berdasarkan hasil wawancara dengan kelompok masyarakat, ruang terbuka hijau penting untuk kehidupan sehari-hari. Pada beberapa kalangan pentingnya RTH itu untuk berekreasi dan bersantai, namun pada kalangan lain nya mengatakan bahwa pentingnya RTH itu untuk meningkatkan status sosial. Saat ini dapat dikatakan RTH di komplek perkantoran Pemerintah Kota Cimahi belum dimanfaatkan dengan optimal. Terlihat dari tidak adanya unggahan foto di sosial media dengan latar belakang RTH di komplek perkantoran Pemerintah Kota Cimahi. Hal tersebut dikarenakan oleh fasilitas dan sarana yang kurang menarik untuk dijadikan latar belakang foto.

Fasilitas yang ada di RTH seharusnya sesuai dengan kondisi di sekitar RTH. Berdasarkan hasil wawancara dengan pengunjung dan hasil observasi ilmiah, dibutuhkan arena bermain anak pada RTH. Hal tersebut dikarenakan terdapat aliran sungai di sebrang RTH, arena bermain anak di RTH akan mengalihkan perhatian anak-anak untuk tidak bermain di sungai. 
Jurnal Planologi Vol. 16, No. 1, April 2019

Available : http://jurnal.unissula.ac.id/index.php/psa

\section{KESIMPULAN DAN SARAN}

\subsection{Kesimpulan}

Berdasarkan hasil penelitian tentang evaluasi kualitas aset ruang terbuka hijau di komplek perkantoran Pemerintah Kota Cimahi, dapat disimpulkan bahwa:

1. Fasilitas-fasilitas untuk mendukung kegiatan pengunjung belum tersedia yang meliputi jalur pejalan kaki dan jogging track yang layak dan aman, arena bermain anak, dan fasilitas khusus untuk penyandang disabilitas. Selain itu, pada area RTH tidak ada personel khusus keamanan dan kurangnya personel untuk pemeliharaan RTH. Kondisi tersebut akan mengurangi motivasi masyarakat atau pengunjung untuk beraktivitas di RTH komplek perkantoran Pemerintah Kota Cimahi.

2. Kurangnya vegetasi yang menyebar, rendahnya tingkat kebersihan, dan keindahan di area RTH komplek perkantoran Pemerintah Kota Cimahi. Arena bermain anak-anak dan lintasan sepeda pun belum tersedia.

3. Penggunaan fasilitas yang ada di RTH komplek perkantoran Pemerintah Kota Cimahi tidak merata. Hal tersebut diakibatkan oleh beberapa fasilitas tertentu jarang bahkan tidak digunakan. RTH di komplek perkantoran Pemerintah Kota Cimahi saat ini belum dimanfaatkan oleh masyarakat sekitar, hal tersebut dikarenakan kondisi RTH yang kurang layak dan fasilitas yang sesuai dengan kondisi area RTH saat ini belum tersedia

\subsection{Saran}

Berdasarkan kesimpulan yang telah dikemukakan, solusi yang direkomendasikan kepada Pemerintah Kota Cimahi yakni merancang kebutuhan aset ruang terbuka hijau agar memenuhi kriteria kualitas sebagai ruang terbuka hijau di kawasan perkotaan.

\section{DAFTAR PUSTAKA}

Hastings, N. (2010). Physical Asset Management. London; Springer.

Malek., Manohar., Mustafa. (2012). The making of a quality neighbourhood park: a path model approach. Procedia Social and Behavioral Sciences 49 (2012) 202 - 214

Muchran, Wahyuni, Machfudz, Susilawati. (2015). Model Perencanaan Ruang Terbuka Hijau Taman Lingkungan Di Kota Banjarbaru Kalimantan Selatan. Enviroscientase. 11 (2015) 19-32.

Peraturan Menteri Pekerjaan Umum No.5 Tahun 2008 tentang pedoman penyediaan dan pemanfaatan ruang terbuka hijau 
Jurnal Planologi Vol. 16, No. 1, April 2019 Available : http://jurnal.unissula.ac.id/index.php/psa

Planning Policy Guidance 17: Planning for Open Space, Sport and Recreation. (2005). Inggris: Department for Communities and Local Government

Sugiama, A. G. (2013). Manajemen Aset Pariwisata. Bandung: Guardaya Intimarta.

Sugiama, A. G. (2013). The Synergistic Model of Quality Service Design of Green Open Space Asset Through QFD. Sustainable Competitive Advantage. 2 (1) 